\title{
Institutional approaches of the Federal Republic of Germany to post-conflict recovery, stabilization and development programs implementation
}

\author{
Sergey Tishkov ${ }^{1}$, Valentina Ogneva ${ }^{2,3}$, and Irina Tishkova ${ }^{4}$ \\ ${ }^{1}$ Lukyanov Orel Law Institute of the Ministry of the Interior of Russia, 302027, Ignatova Str., 2, Orel, \\ Russia \\ ${ }^{2}$ Russian presidential Academy of national economy and public administration, Central Russian \\ Institute of management, 302030, Pobedy Bulevard, 5A, Orel, Russia \\ ${ }^{3}$ Bryansk branch of RANEPA, 241050, Gorkogo Str., 18, Bryansk, Russia \\ ${ }^{4}$ Orel State Agrarian University, 302019, Generala Rodina Str., 69, Orel, Russia
}

\begin{abstract}
The article studies practical approaches of the Federal Republic of Germany to the implementation of post-conflict recovery, stabilization and development programs. Noted that Germany is actively pursuing unilateral and joint programs for global sustainable development or specialized programs in different parts of the world. This good performance became possible due to a new German methodological approach based on complex and flexible usage of diplomacy, development policy and security measures. The well build institutional system under coordination of the Federal Foreign Office and the Federal Ministry for Economic Cooperation and Development is able to fulfill difficult tasks successfully. This point is illustrated by practical experience of the German Agency for International Cooperation, the Reconstruction Loan Corporation and the German Civil Peace Service. The article concludes that Germany achieved significant results in post-conflict recovery, stabilization and development activities because of bringing together efforts of different actors.
\end{abstract}

\section{Introduction}

Resolution of extensive internal conflicts aggravated by violations of human rights and uncontrolled migration required efficient measures from word politic actors. Independent states are trying to find new modalities of collaboration and cooperation in order to create an agenda of international relations based on principles of transparency, rational interdependence and mutual responsibility.

This process is taking place in unstable security environment aggravated by a high level of geopolitical competition, supported by a set of previously unknown challenges and threats.

Therefore, active participation in conflict resolution became an important tool for enhancing the authority of states in the international affairs.

Practical spectrum of conflict resolution activities ranges from diplomatic efforts to peace enforcement executed under umbrella of regional security organizations or military blocs. 
The Federal Republic of Germany contributes to peacekeeping initiatives as an important actor willing to assume increased international responsibility.

Germany views participation in conflict resolution as an important element of foreign policy and national security policy as well as support for United Nations peacekeeping and peacebuilding initiatives.

\section{Materials and methods}

Because of specific subject matter of the study, we have applied well-known interdisciplinary, systemic, historical, institutional and structural-functional scientific approaches.

Based on a comprehensive review of the thematic reports and scientific publications, we identify the characters of German institutional approaches to post-conflict recovery, stabilization and development programs organization and implementation.

\section{Results and Discussion}

Over past decades, the trends of German foreign policy are focused on support of international cooperation for sustainable development and ensuring human rights protection $[1]$.

The Federal Republic of Germany demonstrates not only willingness but also a political will to take responsibility for solving of global problems from conflict resolution to environmental of development issues $[2,3]$.

Along with participation in United Nations-sponsored peacekeeping activities, a new humanitarian and development trends in Germany foreign policy are clearly visible.

As per Organization for Economic Co-operation and Development thematic report on Development Co-operation Profile Germany's official development assistance (ODA) volume is the second-largest among members of Development Assistance Committee.

In 2018, most of Germany's bilateral ODA was allocated to social infrastructure and services with a strong focus on support to government and civil society (USD 3.0 billion), education (USD 2.4 billion) and water supply and sanitation (USD 1.7 billion).

In 2019 the total ODA on a grant-equivalent basis stood at USD 23.8 billion (preliminary data), representing $0.60 \%$ of Germany's gross national income (GNI) for this year [4].

Germany actively contributes to stabilization and provision of basic humanitarian assistance in crisis regions with numerous projects. It work with governments and private actors to create conditions for post-conflict stabilization and sustainable development. These actions are particularly important for post-conflict recovery of affected states because sustainable development is the primary way to ensure the successful social systems in constantly changing resources and factors [5].

The well build institutional system has formed in the country to bring together the efforts of various government and non-government actors.

The overall leadership of the foreign development work is performed by the Federal Foreign Office (Auswärtiges Amt) and the Federal Ministry for Economic Cooperation and Development (Bundesministerium für wirtschaftliche Zusammenarbeit und Entwicklung, $\mathrm{BMZ}$ ).

The Federal Foreign Office coordinates German interests and formulates positions on various topics to develop a unified foreign and security policy. At the same time, it plays the coordinating role in crisis management, human rights protection and overseeing of humanitarian assistance as well. 
The Federal Ministry for Economic Cooperation and Development (BMZ) coordinates development cooperation policy with partner countries and oversees largest part of Germany's ODA.

The head office of this Ministry is located in Bonn well known as a center for national and international development institutions.

The BMZ defines principles and guidelines for the German state development policy. It specifies priority areas, signs agreements with partner countries, and secures financing for bi-lateral development cooperation [6].

The BMZ coordinates with partner countries different programs and projects aimed at ensuring peace and security; democracy, civil society and public administration; human rights protection; education; environmental policy, preservation and sustainable use of natural resources; energy and the climate protection; food security and agriculture; health; water management; sustainable business development based on standards for human rights, welfare and environment [7].

Some of the BMZ's staff regularly posted to other parts of the world on development assignments, as economic cooperation officers at German embassies, for instance.

For the practical work on the ground (such as advising government institutions in partner countries or processing loans and grants for development projects, etc.) the BMZ commission specialized institutions (known as "implementing organizations") to perform this work.

Over the years of work with various actors (implementing organizations, non-government organizations and church), the BMZ contributed a lot for post-conflict recovery, stabilization and development and obtained valuable peacekeeping experience and regional knowledge as well.

For example, in early 1990s when the states of Central, Eastern and South Eastern Europe obtained independence the Federal Republic of Germany has been supporting them to facilitate the difficult economic and social transition contributing to the stability and security of all Europe.

Development activities started with the idea that the political stability, economic growth and peace in this region hinge upon the work of government institutions based on the rule of law, and support of a strong civil society. This will minimize the negative impact of the crisis on all spheres of social life through reducing tension and anxiety, improving the financial situation and quality of life. Finally, this will allow to change people's values and to build the trust.

Obviously, properly functioning state institutions must be supported by a performanceoriented civil service and be placed on a sound financial footing.

That is why the German support to partner states in this region was focused on economic development and employment; supporting reforms in the administration and judiciary to put in place legal certainty and transparency and to foster decentralization; modernization and extension of public infrastructure.

In Bosnia and Herzegovina Germany supported public administration sector reform in order to achieve proper functioning of state and municipal institutions and community oriented management style.

Additionally, Germany helped to strengthen government institutions such as the country's Central Bank and its statistical and public procurement agencies.

In order to foster a social market system in Bosnia and Herzegovina, the German government supported local and regional private-sector development and business selforganization. For instance, at the regional and local levels Germany provided advisory support to the regional and municipal agencies set up in the two entities to promote development and the private sector. Based on cooperation between local authorities, industry 
federations and businesses, strategies were developed to make the towns and municipalities in question more attractive sites for business activities [8].

At present, the BMZ is working on wide spectrum of development programs and projects in different parts of the world. It became possible due to shift of German foreign policy and economic paradigm of crisis management. A new networked approach is based on flexible and coordinated usage of diplomatic tools, development policy and security policy measures according with local conditions.

Germany considers modern crisis management not only as conflict resolution tool or as a way to provide humanitarian aid. It is an important part of German international responsibility for the world's peace and security. This involves multidimensional cooperation of variety of international and national actors to address current challenges.

It is very important, especially during crises, to underpin political goals with tailormade instruments - for example, the rule of law promotion, mediation, the security sector reform or support for coming to terms with the past.

As per statement of Ekkehard Brose, the Special Envoy for Crisis Prevention and Stabilization at the Directorate-General for Crisis Prevention, Stabilization, Post-Conflict Peacebuilding and Humanitarian Assistance (a new department in the Federal Foreign Office founded in 2015), there was an ambition to redefine foreign policy engagement in crisis regions because a modern foreign policy means more than just traditional diplomacy.

Therefore, German government announced the idea of a "new foreign policy toolkit" aimed to pooled personnel, funds and competencies for efficient crisis respond.

In October 2017 the German Government adopted a new guidelines in order to develop conceptual approaches to post-conflict stability. According to this document stabilization was defined as an approach to dealing with violent conflicts that relies on a political process of conflict resolution [9].

At present, the two main branches provided with largest part of Germany's ODA are technical co-operation and financial co-operation. A few government implementing organizations were established for proper planning, coordination and control of development programs and projects.

In particular, the German Agency for International Cooperation (Deutsche Gesellschaft für internationale Zusammenarbeit, GIZ) is the main institutional body for technical cooperation. GIZ works flexibly to deliver effective and efficient solutions that offer people better prospects and sustainably improve their living conditions [10]. The Agency is responsible for advising governments and institutions on the ground, providing funding for executing agencies in the partner countries, producing studies and expert opinions, select and post exerts and aid workers[7].

For example, due to rising attention to the issues of Africa from the EU countries GIZ is playing the leading role in implementation programs and projects under the umbrella of the Federal Foreign Office and the Federal Ministry for Economic Cooperation and Development.

Moreover, the particular focus is paid to Ethiopia accommodated the GIZ Office in Africa.

The German Agency for International Cooperation (GIZ) has been working in Ethiopia on behalf of the German government since 1964.

In recent years Germany is supporting the Ethiopian Government in implementation of an ambitious five-year Growth and Transformation Plan (2015-2020) to achieve the Sustainable Development Goals adopted by the United Nations and double Ethiopia's GDP.

GIZ portfolio in Ethiopia consists of conflict management and promotion of peace and security, urban governance and decentralization, regional economic cooperation, labourmarket-oriented education and training as well development of partnerships with the private sector. 
Quality infrastructure and renewable energies became other important fields of activity for GIZ in Ethiopia.

Taking into account the importance of food security and agriculture development for sustainable use of natural resources the Agency launched a few project with the support of Federal Ministry of Food and Agriculture (Bundesministerium für Ernährung und Landwirtschaft) [11].

Foreign financial cooperation for sustainable development is organized under the general coordination of the Reconstruction Loan Corporation (Kreditanstalt für Wiederaufbau, KfW).

The main institutional bodies of this KfW Corporation are KfW Development Bank responsible for financial cooperation programs with partner countries; awarding of grants, subsided loans, soft loans and subsides; financing of private-sector investments through its subsidiary development finance institutions [7] and KfW International Project and Exportfinanzing Bank (KfW IPEX-Bank) working on medium- and long term earmarked funding for infrastructure development, power and environmental projects, etc. [12].

It is important to highlight that the overall internal evaluation system was created in each government implementation organization in order to ensure financial efficiency of development activities. For example, GIZ's Evaluation Unit performs corporate and technical co-operation project evaluations and reports directly to the Management Board and

KfW Development Bank's Evaluation Department mostly focuses on standard ex post evaluations of individual projects and programs [4].

Non-state actors actively contribute in post-conflict reconstruction, stabilization and development activities as well as their state partners.

Therefore, we would like to discuss the experience of the German Civil Peace Service (Der Zivile Friedensdienst, ZFD) - a program aimed at preventing the outbreak of violence, non-violent conflict resolution and promoting sustainable peace in crisis zones and conflict regions.

The program is running by a number of development and peace organizations joined up to form the Civil Peace Service Consortium (Konsortium Ziviler Friedensdienst) with the financial support of the BMZ [13].Since the foundation of the Civil Peace Service in 1999, more than 1,200 international experts have been working in more than 60 countries [14].

Civil Peace Service seconds experts to assist local partner organizations that

- build structures of cooperation and dialogue across lines of conflict for strengthening of traditional conflict resolution,

- $\quad$ create meeting points and safe spaces where conflict parties can meet,

- $\quad$ strengthen information and communication structures that trace the causes and consequences of violent conflict (including the promotion of peace journalism, the networking of peacebuilding organizations, and monitoring the conflict dynamic),

- $\quad$ provide counselling and social support to groups that are particularly affected by violence for their reintegration into society,

- $\quad$ restore confidence in local law and order, and campaign for human rights,

- develop peace education courses aimed at breaking of "enemy stereotypes",

- provide assistance and training in methods and concepts of civil conflict resolution.

For example, as per German Agency for International Cooperation (ZIF) initiative the ZFD personnel launched projects aimed at dialogue fascination and trust building in the Ethiopian largest state Oromia.

For many years the Oromia was the place of conflicts over access to natural resources between nomadic herdsmen and the sedentary population, between internally displaced persons and host communities, and between the Oromos and other resettled ethnic groups, some of whom live in enclaves. 
These conflicts repeatedly result in violent clashes. The reasons vary but include the use of water, the sharing out of pasture and agricultural land, land titles caught between traditional custom and formal governmental land and resource legislation, and ethnic and religious affiliations.

The main objective of the project was to create trust-based cooperation between the various sectors of the population, traditional authorities, government representatives and nongovernmental organizations to deal with conflicts over land and resources without resorting to violence.

Working with various partners, including Oromia Bureau of Administration and Security, Oromia Pastoralist Association and Evangelical Church Mekane Yesus ZFD experts helped to deal peacefully with an initial three conflicts over access to land and water resources.

ZFD supported discussions between representatives from the various communities (including the elders) and between these and government representatives for proper and peaceful use of natural resources.

Traditional methods of boundary marking as well as participatory mapping of plots and conflict-sensitive resource management, including water management concepts and shared use of pasture for nomads were applied. ZFD also promoted the planting of trees for the restoration of the environment. Mini-projects such as joint children's, sports and cultural events boost trust further.

The Oromia case experience confirm that inclusive and participatory dialogue is the key factor to build mutual trust between involved parties and to identify the cause and drivers of internal conflict. Empowerment of local women and young people allowing them to play an active role in the dialogue processes and to make their specific needs heard is the additional possibility for peaceful conflict resolution.

The best practices gained from these projects are discussed, honed and passed on. The key practical lessons learned for the resolution of conflicts related to natural resources are the development of resource management concepts (for example, land-use plans), concluding agreements on resource usage limits and on joint regulations to penalize violence [15].

We are sure that, wide dissemination of descried experience among locals in and beyond the project region will help to recognize and exploit the benefits of dialogue as a way to deal with conflicts over land and resources without resorting to violence.

In addition to planning and managing programs and projects in the field, development and peace organizations working under umbrella of the Civil Peace Service Consortium also select and deploy civilian personnel to crisis regions. During the project implementation field staff is provided with advisory support for better achievement of goals set.

Some of the member organizations provide courses and expert seminars in non-violent conflict resolution for their personnel or candidates for civil peace work. These include Action Committee Service for Peace (AGDF), "KURVE Wustrow" - Centre for Training and Networking in Nonviolent Action, and other organizations. This practice-oriented training increases efficiency of civilian personnel performance within post-conflict recovery, stabilization and development work.

\section{Conclusions}

At present Federative Republic of Germany is playing an important role in unilateral and multilateral cooperation aimed at global stability and peace based on rule of the law and providing international support for sustainable development.

A new humanitarian and development vectors are noted in the Germany's foreign policy along with participation in United Nations-led peacekeeping activities. 
Those trends became possible due to a new German networked approach based on complex and flexible usage of diplomacy, development policy and security policy measures.

The well build institutional system bringing together the efforts of state and non-state actors has been formed in the country. The overall leadership of the foreign development work is performed by the Federal Foreign Office and the Federal Ministry for Economic Cooperation and Development. A few government institutions were established for proper planning, coordination and control of development programs and projects in close cooperation with non-state actors associated with the German Civil Peace Service Consortium.

The valuable results of German post-conflict recovery, stabilization and development work became possible due to effective integrated efforts of state and non-state actors.

\section{References}

1. M. Otte, A Rising Middle Power: German Foreign Policy in Transformation (2001)

2. N.V. Pavlov, Polis. PoliticalStudies, 6, 22 (2019)

3. N.N. Kudashova, Ethnosociety and international culture, 7(145), 74 (2020)

4. OECDilibrary, https://www.oecd-ilibrary.org/

5. E.M. Bobkova, Society: Sociology, Psychology, Pedagogics,12, 18 (2016)

6. German Development Cooperation Work, https://www.bmz.de/

7. Bundesministerium für wirtschaftliche Zusammenarbeit und Entwicklung, http://www.bmz.de/

8. Euer Link zu Deutschland, https://www.deutschland.de/

9. Deutsche Gesellschaft für Internationale Zusammenarbeit (GIZ) GmbH, www.giz.de/

10. Deutsche Gesellschaft für Internationale Zusammenarbeit (GIZ) GmbH, https://www.giz.de/

11. KFW IPX-Bank. Bank aus Verantwortung, https://www.kfw-ipex-bank.de/

12. OECDilibrary, https://www.oecd-ilibrary.org/

13. Ziviler Friedensdienst, https://www.ziviler-friedensdienst.org/

14. Ziviler Friedensdienst, https://www.ziviler-friedensdienst.org/

15. Deutsche Gesellschaft für Internationale Zusammenarbeit (GIZ) GmbH, https://www.giz.de/ 